\title{
CLINOROTATION AS A PROMISING AND ENVIRONMENTALLY FRIENDLY BIOTECHNOLOGY IN AGRICULTURE AND SOME INDUSTRIES
}

\author{
A. L. Boyko *1, N. P. Sus ${ }^{1}$, O. A. Boyko ${ }^{2}$, A. V. Orlovskyi ${ }^{3}$ \\ ${ }^{1}$ Institute of Agroecology and Environmental Management, NAAS of Ukraine, \\ 12, Metrolohichna Str, Kyiv, 03143 Ukraine \\ ${ }^{2}$ National University of Life and Environmental Sciences of Ukraine, \\ 15, Heroyiv Oborony Str, Kyiv, 03041 Ukraine \\ ${ }^{3}$ Institute of Horticulture, NAAS, 6, Sadova Str., Novosilky village, \\ Kyiv-Sviatoshyn District, Kyiv Region, Kyiv, 03027 Ukraine
}

E-mail: boiko.anatolii@email.ua*,email@nazariy-sus.com,olga_bojko@ukr.net,mumuk6500@gmail.com

Received June 03, 2020 / Received June 26, 2020 / Accepted July 20, 2020

\begin{abstract}
Aim. To investigate the direct and indirect impact of clinorotation on vital activity of gilled mushrooms (Agaricales) using the mycelium of the model organism Agaricus bisporus, clinorotated by the ground-based facility Ekoloh, as the example. Methods. The mycelium of Agaricus bisporus was cultivated on the medium with agar and compost extract. The microgravitational environment was simulated using the method of uniaxial clinorotation at the ground-based facility Ekoloh. The mycelia of Agaricus bisporus from the experimental group were clinorotated for $4 \mathrm{~h}$ a day for 12 days. The samples from the control group were cultivated in normal $(1 \mathrm{~g})$ conditions. The simulated gravitational acceleration value was $3.5 \times 10^{-4} \mathrm{~g}$ at the rotational velocity of $2.5 \mathrm{rpm}$ and the rotation radius of $0.05 \mathrm{~m}$. The centrifugal acceleration, affecting the mycelium of Agaricus bisporus under clinorotation, was $0.00343 \mathrm{~m} / \mathrm{s}^{2}$. The two-way ANOVA analysis demonstrated that the effects of g-level, the duration of the impact and their interaction were all statistically significant. At the same time, $73.1 \%$ of the variance in mycelium growth coefficient was triggered by the simulated value of the g, i.e. the duration of the impact was a minor factor. Results. Clinorotation stimulated growth and development of gilled mushroom (Agaricales) mycelium. In particular, in this study the clinorotated mycelium of Agaricus bisporus had approximately 3.4, 2.5, 1.6 times higher coefficients of mycelium growth compared against the mycelium, cultivated in stationary conditions $(1 \mathrm{~g})$ on day 5,10 , and 15 of the cultivation respectively. Contrary to the control mycelial colonies, the growth of clinorotated mycelial colonies of Agaricus bisporus was asymmetric. The direction of the gravitational acceleration vector regarding mycelium colonies was constantly changing in the microgravitational environment, simulated by the ground-based facility Ekoloh. At the same time, different organs of Agaricus bisporus are characterized by gravitropism of different orientation. Therefore, constant changes in the direction of gravitational acceleration vector regarding mycelium could have caused constant re-orientation of mycelium cells in terms of the gravitational acceleration vector, and thus, multidirectional asymmetric growth. In addition, the centrifugal acceleration, generated during clinorotation, is a mechanostimulator, capable of triggering stress responses in different living systems. The accelerated growth is one of the stress responses. At the same time, mycelium could expand in the environment mechanically due to the impact of centrifugal acceleration. However, the centrifugal acceleration was insignificant, thus, we believe that the main effect was caused by microgravity. Conclusions. Since clinorotation stimulates the growth and development of gilled mushrooms and is an efficient way of forming virus-free planting material of different plants, this technology may have a wide scope of application. It may be used in agriculture, forestry and different industries, using raw plants or mushrooms, for instance, in food, pharmaceutical and textile industries, etc.
\end{abstract}

Key words: Agaricus bisporus, clinorotation, simulated microgravity, mycelium, Agaricales. DOI:

\section{INTRODUCTION}

The direction of the gravitational acceleration vector has been the only constant and ever-present abiotic factor during phylogenesis of all the currently existing taxa (Anken R 2013). However, the modulus of the gravitational acceleration vector (hereinafter the gravi-

(C) A. L. BOYKO, N. P. SUS, O. A. BOYKO, A. V. ORLOVSKYI, 2020 
tational acceleration vector will be marked as $\overrightarrow{\mathrm{g}}$ ) is in the range from $9.76392 \mathrm{~m} / \mathrm{s}^{2}$ (the Nevado Huascarán summit, Peru) to $9.83366 \mathrm{~m} / \mathrm{s}^{2}$ (the Arctic Ocean) on the surface of the Earth (Hirt C et al. 2013). This variability in the $\vec{g}$ modulus is insignificant, for instance, the modulus of $\vec{g}$ on the Moon is $0.17 \mathrm{~g}$ ( $\mathrm{g}$ - standard value of the gravitational acceleration, which is 9.80655 $\mathrm{m} / \mathrm{s}^{2}$ and is used here as an acceleration unit), while on Mars it is $0.38 \mathrm{~g}$ (Beysens D A, A. van Loon J J W 2015). The study on direct and indirect impact of $\vec{g}$ on vital activity of living systems is relevant to understand the specificities of functioning of these biosystems in both micro-g, and hypo-g environments on Mars or Moon (Beysens D A, van Loon J J W A 2015). In addition, clinorotation as one of the methods of simulating transformed environments with alternative values of direction and modulus of $\vec{g}$ (hereinafter - transformed environment) is also an efficient method of treating plants, infected with tobacco mosaic virus (TMV), wheat streak mosaic virus (WSMV), potato virus M (PVM), potato curly dwarf virus (PCDV) and other viruses (Sus N et al. 2018). Furthermore, according to the results of our study, clinorotation stimulates the growth and development of Agaricus bisporus mycelium (JE Lange) Imbach, 1946. Therefore, the investigation of the vital activity of biosystems in transformed environments promotes solving some fundamental problems of life sciences along with applied problems of agriculture, food and pharmaceutical industries, etc.

However, as the possibilities of research in space flight conditions are limited, transformed environments are usually simulated using ground-based facilities (GBFs). Since Julius von Sachs designed the first clinostat in 1879, many types of ground-based facilities have been elaborated to simulate media with alternative orientations or moduli of the $\vec{g}$. The process of simulating transformed environments using all these ground-based facilities is based on one of two principles: compensation of the $\vec{g}$ with diamagnetic levitation or randomization of the direction of the $\vec{g}$ regarding the sample over time via its rotation around one or several axes (clinostats and other rotating facilities) (Beysens D A, A. van Loon J J W A 2015; Herranz R et al. 2013). Different types and models of the same kind of ground-based facility have different structural and operational characteristics (Beysens D A, A. van Loon J J W A 2015; Herranz R et al. 2013). These differences clearly determine parameters of the transformed environment, simulated by a specific GBF. In this article, we also give detailed description of structural and operational characteristics of the ground-based facility Ekoloh (Furdychko O et al. 2020), used to simulate a transformed environment.

The ground-based facility Ekoloh was used in our previous study, aimed at investigating the impact of clinorotation on the course of viral infections in plants (Sus $\mathrm{N}$ et al. 2018). For instance, this study demonstrated that clinorotation of tobacco plants (Nicotiana tabacum L.), infected with TMV, resulted in a considerable reduction in the number of viral inclusion bodies and the recovery of these plants (Sus N et al. 2018). The current study is the continuation of the abovementioned previous one. The object of this study is also clinorotation but the subject is direct and indirect impacts of clinorotation on vital activity of gilled mushrooms (Agaricales). The species of this fungal order are very important for agriculture, food, pharmaceutical and other industries. However, there are scarce data about gravitropism and specificities of vital activity of these species in real or simulated microgravity. One of the species of this order, regarding whose sensitivity to changes in the direction of the $\overrightarrow{\mathrm{g}}$ there are some data, is Agaricus bisporus (Nevalainen H 2020). The fruiting bodies of this mushroom have negative gravitropism (i.e. they are directed towards the ground). At the same time, lamellae (gills) of A. bisporus have positive gravitropism. In response to the change in direction of the $\overrightarrow{\mathrm{g}}$, the gills of this mushroom are re-oriented within one hour (MOORE D 1991; Corrochano L M, Galland P 2016). Therefore, A. bisporus is sufficiently sensitive to the changes in the direction of the $\vec{g}$ to be used as a model organism in this study. In addition, this mushroom is one of the most frequently cultivated in the world, often used as a model organism in different studies (Nevalainen H 2020). Having taken the abovementioned facts into consideration, we selected A. bisporus to be the model organism in this study.

Therefore, this study was aimed at investigating the direct and indirect impact of clinorotation on vital activity of gilled mushrooms (Agaricales) using the mycelium of the model organism Agaricus bisporus, clinorotated by the ground-based facility Ekoloh, as the example.

\section{MATERIALS AND METHODS}

Mushroom material and growth conditions. The mycelium of $A$. bisporus was cultivated on the medium with agar and compost extract. The medium was prepared by extracting compost $(0.4 \mathrm{~kg})$ with tap water $\left(0.001 \mathrm{~m}^{3}\right)$ for $24 \mathrm{~h}$ and further multiple filtering and adding agar $(0.02 \mathrm{~kg})$. Then this medium was autoclaved (for at least $25 \mathrm{~min}$ ) at $101{ }^{\circ} \mathrm{C}$. The mycelium 
of $A$. bisporus in both control and experimental groups was cultivated in this environment in glass tubes (h $210 \mathrm{~mm}, \varnothing 20 \mathrm{~mm})$ at $20{ }^{\circ} \mathrm{C}$ and daily 14 -h photoperiod. The control group was cultivated in normal environment $(1 \mathrm{~g})$. The samples from the experimental group were clinorotated clockwise using the groundbased facility Ekoloh in mode 1 (see subsection "Operating modes of the facility Ekoloh" in RESULTS). The rotational frequency was $2.5 \mathrm{rpm}$. The samples were clinorotated for $4 \mathrm{~h}$ a day for 15 days. Every five days the coefficient of mycelium growth $\left(\mathrm{C}_{\text {mycelium growth }}\right)$ was calculated using the formula:

$$
\mathrm{C}_{\text {mycelium growth }}=\frac{\mathrm{d} \times \mathrm{h} \times \mathrm{g}}{\mathrm{t}},
$$

where $\mathrm{d}$ is the diameter of the mycelial colony (in $\mathrm{mm}$ ), $\mathrm{h}$ is the height of the mycelial colony (in $\mathrm{mm}$ ), $\mathrm{g}$ is the density of the mycelial colony (in points on a threepoint scale), and $t$ is the age of mycelial colony (in days) (Sysoeva M A et al. 2020).

The diameter of the colony is the average value of the length of two segments, namely, the segment, connecting two most remote opposite edges of the colony and the segment, connecting two opposite edges of the colony and perpendicular to the first segment.

Artifacts of the work of the ground-based facility Ekoloh. The ground-based facility Ekoloh (hereinafter facility Ekoloh) was developed by the Research Design and Technology Bureau of the National Scientific Center "Institute of Mechanization and Electrification of Agriculture" NAAS to the order and by the scientific design of the Laboratory of Viral Ecology and Biosafety of the Department of Agroecology and Biosafety of the Institute of Agroecology and Environmental Management of NAAS to simulate environments with altered modulus and direction of the $\vec{g}$. The facility Ekoloh constantly alters the orientation of the samples in terms of direction of the $\vec{g}$ rotating them either around the axis, perpendicular to the direction of the $\vec{g}$ (slow uniaxial clinorotation) or around the axis, parallel to the direction of the $\overrightarrow{\mathrm{g}}$ (slow centrifugation), or around two axes, one of which is parallel and the other - perpendicular to the direction of the $\overrightarrow{\mathrm{g}}$ (slow biaxial clinorotation), thus reducing the perception of the $\overrightarrow{\mathrm{g}}$ by these organisms.

However, the rotation of samples by the facility Ekoloh also generates centrifugal acceleration, impacting the sample in the rotating reference frame. The centrifugal acceleration is a typical side effect of clinostats and other rotating facilities which may mask or distort the desired effect of the randomization of the direction of the $\vec{g}$ regarding the sample. As the facility Ekoloh rotates the sample with constant angular velocity and the samples do not move within the rotating reference frame (in this experiment), a tangential acceleration and the Coriolis acceleration were not calculated in this paper (Kim Y J et al. 2017).

The centrifugal acceleration for the rotation around one axis, like the one in a clinostat or centrifuge, can be calculated (in $\mathrm{m} / \mathrm{s}^{2}$ ) using the formula:

$$
\mathrm{a}_{\text {centrifugal }}=\omega^{2} \mathrm{r} \text {, }
$$

where $\omega$ is angular velocity (in $\mathrm{rad} \mathrm{s}^{-1}$ ) and $\mathrm{r}$ is the distance from the center of rotation (in $\mathrm{m}$ ).

The angular velocity was calculated using the formula:

$$
\omega=\frac{2 \pi}{\mathrm{T}}
$$

where $\mathrm{T}$ is the rotation period (in s) (Brungs $\mathrm{S}$ et al. 2016; Brungs S et al. 2019; Van Loon J J W A 2016).

Statistical analyses. The values of mycelium growth coefficient were indicated as the mean \pm standard deviation. The effects of clinorotation were analyzed via two-way ANOVA (the factors being g-level and duration of exposure) using the Analysis ToolPak (free addin to Microsoft Excel). The calculated p-values were adjusted using the Bonferroni correction to

$$
\alpha=\frac{0.05}{6}=0.0083
$$

where the divisor (6) is the number of independent comparison groups.

The size of the effect of a specific factor was estimated via calculation of the Eta squared $\left(\eta^{2}\right)$ :

$$
\eta^{2}=\frac{\mathrm{SS}_{\text {effect }}}{\mathrm{Ss}_{\text {total }}}
$$

where $\mathrm{SS}_{\text {effect }}$ is the sum of squares of the corresponding effect, and $\mathrm{SS}_{\text {total }}$ is the total sum of squares for all effects, interactions, and errors (Batitucci G et al. 2019).

\section{RESULTS}

Structure of the facility Ekoloh. A facility Ekoloh consists of a cross-shaped platform and a block of chambers that are rotated independently by two different shafts (axles) and can be rotated regardless of one another clockwise or counterclockwise. The crossshaped platform can continuously rotate around an axis parallel to the direction of the $\overrightarrow{\mathrm{g}}$ (hereinafter the axis, around which the cross-shaped platform rotates, is called "a platform rotation axis") both clockwise and counterclockwise. The block of chambers consists of six chambers, fixed on the cross-shaped platform. 

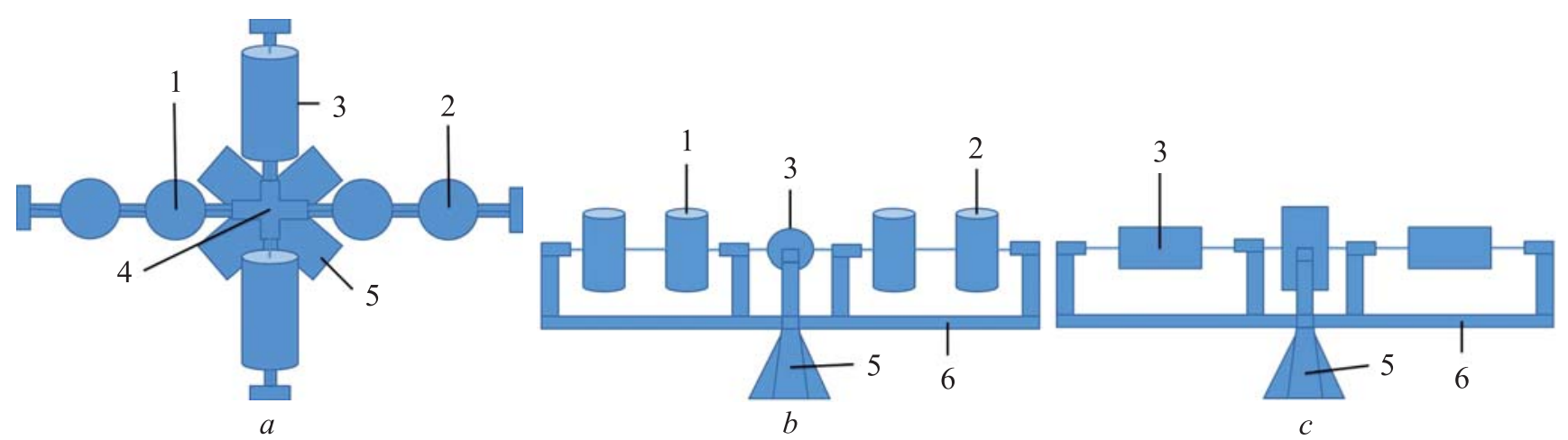

Fig. 1. The scheme of the facility Ekoloh: $a$ - top view; $b, c$ - side view; 1 - type 3 chambers (C-3); 2 - type 2 chambers (C-2); 3 - type 1 chambers (C-1); 4 - a shaft (axle) of a block of chambers; 5 - support (bed); 6 - cross-shaped platform

These chambers are shaped as a right circular cylinder withe the radius of $5 \mathrm{~cm}$ and the height of $27 \mathrm{~cm}$. The chambers rotate clockwise or counterclockwise regardless of the cross-shaped platform. According to the distance between a chamber center (the geometric center (centroid) of the right circular cylinder (i.e. chamber), hereinafter referred to as the chamber center) and the platform rotation axis and the relation between the chamber axis (i.e. the imaginary segment, connecting the centers of bases of the chamber, hereinafter referred to as the chamber axis) and the chamber rotation axis (hereinafter, the chamber rotation axis the axis around which the proper rotation of the chamber takes place regardless of the rotation of the crossshaped platform), the chambers are divided into three different types: type 1 chambers, type 2 chambers, and type 3 chambers. Type 1 chambers $(\mathrm{C}-1)$ rotate around the axis, perpendicular to the direction of the $\overrightarrow{\mathrm{g}}$. Their chamber axis is parallel to their chamber rotation axis and the direction of the $\overrightarrow{\mathrm{g}}$. Type 2 chambers (C-2) and type 3 chambers (C-3) rotate around the axis, perpendicular to the direction of the $\overrightarrow{\mathrm{g}}$, and their chamber axes are perpendicular to their chamber rotation axes. Contrary to C-2, C-3 is located closer to the platform rotation axis, the distance between the platform rotation axis and the chamber center in C-2 is $36 \mathrm{~cm}$. On the contrary, the distance between the platform rotation axis and the chamber center in C-3 is $22.5 \mathrm{~cm}$ (Fig. 1).

Operating modes of the facility Ekoloh. The facility Ekoloh combines a clinostat and a centrifuge. This facility can work in the following modes:

- the horizontal uniaxial clinorotation mode (hereinafter - mode 1 or M1) and the vertical uniaxial clinorotation mode (hereinafter - mode 2 or M2) that provide the rotation of the samples around the axis perpendicular to the direction of the $\overrightarrow{\mathrm{g}}$ (true uniaxial clinorotation). Contrary to M1, the chamber axis in M2 is perpen- dicular to the chamber rotation axis, whereas in mode 1 these axes are parallel. For clinorotation in mode 1, the samples are placed into $\mathrm{C}-1$, and for clinorotation in mode 2 - into C-2 or C-3, setting the relevant operating mode of the facility Ekoloh (Fig. 1);

- the modes of slow centrifugation, where the samples co-rotate with the cross-shaped platform around the axis, parallel to the direction of the $\overrightarrow{\mathrm{g}}$. In these modes the chambers do not rotate around the chamber rotation axis. Relative to the distance from the platform rotation axis to the chamber center and the relation between the chamber axis and the direction of the $\overrightarrow{\mathrm{g}}$, the modes of slow centrifugation are divided into three modes: horizontal slow centrifugation mode (hereinafter mode 3 or M3), large radius slow vertical centrifugation mode (hereinafter mode 4 or M4) and small radius slow vertical centrifugation mode (hereinafter mode 5 or M5). Contrary to modes 4 and 5 , in mode 3 the chamber axis is perpendicular to the direction of the $\vec{g}$, whereas in modes 4 and 5 they are parallel. The relation between the chamber axis to the direction of the $\vec{g}$ or the chamber rotation axis is relevant for the rotation of some organisms (for instance, higher fungi and plants) with a normal living position (vertical position). The rotation radius of the samples in mode 5 is smaller than in mode $4,22.5 \mathrm{~cm}$ against $36 \mathrm{~cm}$ respectively, so these modes are different. C-1 is used in M3, whereas C-2 and C-3 are used in M4 and $\mathrm{M} 5$ respectively (Fig. 1);

- biaxial clinorotation modes, which are also divided into three kinds by the distance from the platform rotation axis to the chamber center and the relation of the chamber axis to the chamber rotation axis: horizontal biaxial clinorotation mode (hereinafter - mode 6 or M6), large radius vertical biaxial clinorotation mode (hereinafter - mode 7 or M7) and small radius vertical biaxial clinorotation mode (hereinafter - mode 8 or 
M8). In these modes, the chambers with samples rotate simultaneously around the chamber rotation axis and the platform rotation axis. Thus, each of these modes combines the mode of uniaxial clinorotation and the mode of slow centrifugation, namely, M6 combines M1 and M3, while M7 combines M2 and M4, and M8 combines M2 and M5, respectively. The same chambers are used for modes of biaxial clinorotation and for the modes they combine.

It is noteworthy that this description and classification of operating modes of the ground-based facility Ekoloh do not take into account the direction of rotation (clockwise or counterclockwise). Since the classification, taking into account the rotation direction, would envisage 22 operating modes of the groundbased facility Ekoloh, we specify the rotation direction along with the operating mode, because such a vast number of operating modes complicates its understanding.

Centrifugal acceleration and some rotation parameters for the operating modes of the facility Ekoloh. Centrifugal acceleration is the main side effect (artifact) of the clinorotation method. Therefore, we calculated centrifugal acceleration for the samples, rotated by the facility Ekoloh in modes M1, M2, M3, M4 and M5 respectively, using equation 2 . The values of their centrifugal acceleration are presented in Table. The centrifugal acceleration and other parameters of biaxial clinorotation are not considered in this article. In addition, Table 1 presents the values of angular velocity, equivalent to different values of rotational frequency according to equation 3 . This is a constant ratio, i.e. it does not depend on the radius, thus, relevant values of the angular velocity may be used to describe both any

Centrifugal acceleration and some rotation indices for the operating modes of the ground-based facility Ekoloh

\begin{tabular}{c|c|c|c|c|c|c}
\hline \multirow{2}{*}{$f, \mathrm{rpm}$} & \multirow{2}{*}{$\omega, \mathrm{rad} / \mathrm{s}$} & \multicolumn{4}{|c}{ Centrifugal acceleration, $\mathrm{m} / \mathrm{s}^{2}$} \\
\cline { 3 - 7 } & & $\mathrm{M} 2$ & $\mathrm{M} 3$ & $\mathrm{M} 4$ & $\mathrm{M} 1$ & $\mathrm{M} 1$ \\
\cline { 3 - 7 } & & $\mathrm{R}=0.05 \mathrm{~m}$ & $\mathrm{R}=0.135 \mathrm{~m}$ & $\mathrm{R}=0.31 \mathrm{~m}$ & $\mathrm{R}=0.36 \mathrm{~m}$ & $\mathrm{R}=0.225 \mathrm{~m}$ \\
\hline \multirow{2}{*}{1} & 0.105 & 0.00055 & 0.00148 & 0.00340 & 0.00395 & 0.00247 \\
1.5 & 0.157 & 0.00123 & 0.00333 & 0.00765 & 0.00888 & 0.00555 \\
2 & 0.209 & 0.00219 & 0.00592 & 0.01360 & 0.01579 & 0.00987 \\
2.5 & 0.262 & 0.00343 & 0.00925 & 0.02125 & 0.02467 & 0.01542 \\
3 & 0.314 & 0.00493 & 0.01332 & 0.03060 & 0.03553 & 0.02221 \\
4 & 0.419 & 0.00877 & 0.02369 & 0.05439 & 0.06317 & 0.03948 \\
5 & 0.524 & 0.01371 & 0.03701 & 0.08499 & 0.09870 & 0.06169 \\
6 & 0.628 & 0.01974 & 0.05330 & 0.12238 & 0.14212 & 0.08883 \\
7 & 0.733 & 0.02687 & 0.07254 & 0.16658 & 0.19344 & 0.12090 \\
8 & 0.838 & 0.03509 & 0.09475 & 0.21757 & 0.25266 & 0.15791 \\
9 & 0.942 & 0.04441 & 0.11992 & 0.27536 & 0.31978 & 0.19986 \\
10 & 1.047 & 0.05483 & 0.14804 & 0.33995 & 0.39478 & 0.24674 \\
11 & 1.152 & 0.06635 & 0.17913 & 0.41134 & 0.47769 & 0.29856 \\
12 & 1.257 & 0.07896 & 0.21318 & 0.48953 & 0.56849 & 0.35531 \\
13 & 1.361 & 0.09266 & 0.25019 & 0.57452 & 0.66719 & 0.41699 \\
14 & 1.466 & 0.10747 & 0.29017 & 0.66631 & 0.77378 & 0.48361 \\
15 & 1.571 & 0.12337 & 0.33310 & 0.76489 & 0.88826 & 0.55517 \\
16 & 1.676 & 0.14037 & 0.37899 & 0.87028 & 1.01065 & 0.63165 \\
17 & 1.780 & 0.15846 & 0.42785 & 0.98246 & 1.14093 & 0.71308 \\
18 & 1.885 & 0.17765 & 0.47966 & 1.10145 & 1.27910 & 0.79944 \\
19 & 1.990 & 0.19794 & 0.53444 & 1.22723 & 1.42517 & 0.89073 \\
20 & 2.094 & 0.21932 & 0.59218 & 1.35981 & 1.57914 & 0.98696 \\
\hline
\end{tabular}

Note. $f$ is the rotational frequency (in rpm, rotations per minute); $\omega$ is the angular velocity (in rad s ${ }^{-1}$ ); M1-M5 are the centrifugal accelerations (in $\mathrm{m} / \mathrm{s}^{2}$ ) of the samples, rotated by the ground-based facility Ekoloh in operating modes 1-5, respectively, at the appropriate rotational frequency $(f)$ or angular velocity $(\omega)$; R is the rotation radius of the chamber, rotated by the groundbased facility Ekoloh in the appropriate mode (in m). 
BOYKO et al.

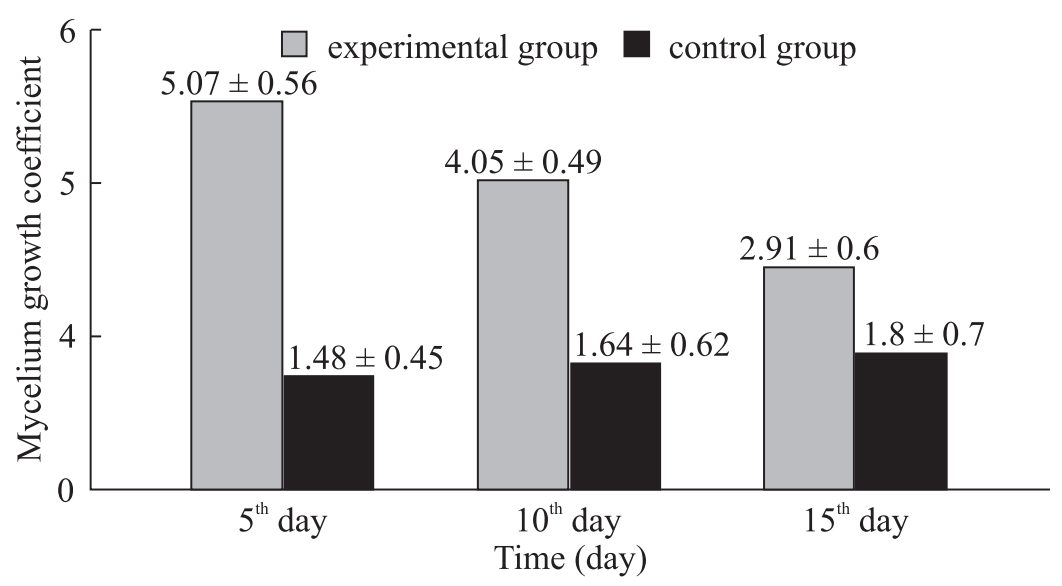

Fig. 2. The growth coefficients of Agaricus bisporus mycelium at the impact of different levels of $g$ and different duration of the impact: the control group - mycelium growth coefficients (mean \pm standard deviations) at the impact of $1 \mathrm{~g}$ for 5,10 , and 15 days of impact, and the experimental group - mycelium growth coefficients (mean \pm standard deviations) at the impact of the simulated value of $g$ and the same duration of the impact

uniaxial modes of the facility Ekoloh, and any uniaxial clinorotation or centrifugation.

Clinorotation of mycelial colonies of Agaricus bisporus. Using equation 1 , we calculated growth coefficient for $A$. bisporus mycelium on days 5,10 , and 15 of the cultivation both in the control and experimental groups. The ratio between these mycelium growth coefficients is presented in Figure 2.

At the same time, the results of the two-way ANOVA analysis demonstrated that g-level ( $1 \mathrm{~g}$ and the simulated value of $g$ ), the duration of the exposure, and their interaction have statistically significant impact on growth coefficients of Agaricus bisporus mycelium. In particular, p-values for the impact of the g-level, the duration of the exposure and their interaction were $1.87 \times 10^{-11}, 8.2 \times 10^{-4}$ and $2.98 \times 10^{-5}$, respectively. To reject or accept zero hypotheses about the absent impact of the g-level, the duration of the exposure, or the impact of their interaction, we compared the relevant obtained statistical F-values $\left(\mathrm{F}_{\text {obt }}\right)$ against the critical F-values $\left(\mathrm{F}_{\text {crit }}\right)$ (using Bonferroni correction). As a result, the obtained statistical F-values for the impact of g-level, the duration of the exposure and their interaction on the variance in the mycelium growth coefficient were $215.18,10.82$ and 19.65 and exceeded the critical F-values, which were $8.79,6.33$ and 6.33 , respectively. Thus, all the abovementioned zero hypotheses were rejected. According to equation 4, we calculated the Eta squared (effect size) for the impact of g-level, the duration of the exposure and for their interaction. It was determined that the Eta squared for the impact of g-level was 0.731 , for the duration of the exposure -0.0735 and for their interaction -0.133 . In these conditions,
$73.1 \%$ of the variance in mycelium growth coefficient can be explained by different levels of g; $7.3 \%$ - by different duration of the exposure, and $13.3 \%$ - by their interaction.

\section{DISCUSSION}

To calculate the simulated value of the $\vec{g}\left(g^{\prime}\right)$, generated by different rotating ground-based facilities, some researchers (Siamwala J H et al. 2010; Arunasri K H et al. 2013; Qian A R et al. 2012; Siamwala J H et al. 2010) used the formula: $\mathrm{g}^{\prime}=\omega^{2} \mathrm{r} / \mathrm{g}_{0}$, where $\omega$ - the angular velocity (in $\mathrm{rad} \mathrm{s}^{-1}$ ), $\mathrm{r}$ - the rotation radius (in $\mathrm{m})$ and $\mathrm{g}_{0}$ - the standard terrestrial gravitational acceleration, which is $9.8 \mathrm{~m} / \mathrm{s}^{-1}$. In this study, $\mathrm{g}^{\prime}$ was $3.5 \times 10^{-4} \pm 14 \times 10^{-5}$ (the deviation is based on the tube diameter) at the angular velocity of $0.262 \mathrm{rad} / \mathrm{s}$ and the rotation radius of $0.05 \mathrm{~m}$. According to the common classification, if $\mathrm{g}^{\prime}$ is below $1 \times 10^{-3} \mathrm{~g}$, then this environment is called simulated microgravity, and if $\mathrm{g}$ is below $1 \mathrm{~g}$, but above $1 \times 10^{-3} \mathrm{~g}$, then this environment is called simulated hypogravity (Beysens DA, A. van Loon J J W A 2015; Herranz R et al. 2013). Therefore, the samples of the experimental group were cultivated in the microgravitational environment. The centrifugal acceleration was $0.00343 \pm 0.0014$ (the deviation is based on the tube diameter) $\mathrm{m} / \mathrm{s}^{2}$ and was insignificant.

Contrary to $A$. bisporus mycelium in the control group, cultivated in normal ( $1 \mathrm{~g}$ ) environment, $A$. bisporus mycelium in the experimental group had higher coefficients of mycelium growth. There may be several reasons of this phenomenon. One of the reasons may be constant reorientation of mycelium regarding the direction of the $\overrightarrow{\mathrm{g}}$, which could cause some "gravitropic failure" that could trigger the growth in all directions in 
response to the stressor to restore normal orientation. It is noteworthy that this multidirectional growth was asymmetric. In addition, our pilot experiments in cultivating A. bisporus and Agaricus arvensis Schaeff., 1774 on other media and with other clinorotation parameters also demonstrated the increase in mycelium growth coefficients. Another reason for this phenomenon may be centrifugal acceleration (we did not differentiate between the impact of centrifugal acceleration and simulated value of $g$ ) which may cause the dislocation of parts of the mycelium and thus its gradual expansion in the medium. These effects of clinorotation may also be caused by the synergistic effect of centrifugal acceleration and simulated $\mathrm{g}^{\prime}$. Regardless of the fact that the value of the centrifugal acceleration was insignificant, to distinguish between the effects of centrifugal acceleration and simulated value of the $\mathrm{g}^{\prime}$ it is necessary to study the effect of slow centrifugation on vital activity of $A$. bisporus mycelium, as the centrifugation does not change the orientation of samples regarding the direction of the $\overrightarrow{\mathrm{g}}$. At the same time, in addition to the impact of the $\vec{g}$ (and the centrifugal acceleration, since their effects are inseparable in this study, because the value of the centrifugal acceleration defines $g^{\prime}$ ), the variance in the mycelium growth coefficient also in part depended on the duration of clinorotation, thus, it is important to investigate the impact of long-term clinorotation on the vital activity of $A$. bisporus mycelium and gilled mushrooms in general. In addition, we observed the decrease in the difference between the mycelium growth coefficients of the experimental group and the control group over time, so these indices are likely to get leveled over time, but it is also interesting, in which way the ratio between these indices would change after their leveling, as the mycelium of the experimental group could have been exhausted due to this "extreme" growth. Thus, many questions are yet to be answered.

Summing up the discussion, we can state that, regardless of some indiscernibility of the effects of centrifugal acceleration and the simulated value of the $\mathrm{g}^{\prime}$, firstly, clinorotation stimulates the growth and development of mycelium of some gilled mushrooms, and, secondly, it stimulates the recovery of plants, infected with some viruses (Mishchenko L T et al. 1999). Therefore, clinorotation is not only a method of simulating environments with the altered modulus and direction of the $\vec{g}$, but also a new and environmentally friendly technology which may be used in different branches of agriculture and many industries.

\section{CONCLUSIONS}

The variance in mycelium growth coefficient (as a complex index of mycelium growth and development) was studied for the model organism Agaricus bisporus, conditioned by the impact of different levels ( $1 \mathrm{~g}$ and simulated micro-g) of the gravitational acceleration vector and different duration of the exposure $(5,10$, and 15 days with the exposure of $4 \mathrm{~h} /$ day), to model the specificities of growth and development of the gilled mushrooms (Agaricales order) in the microgravitational environment. The value of the abovementioned level of micro-g, simulated in this study using the method of uniaxial clinorotation at the ground-based facility Ekoloh, was $3.5 \times 10^{-4} \pm 14 \times 10^{-5}$ at the constant angular velocity of $0.262 \mathrm{rad} / \mathrm{s}$ and the rotation radius of $0.05 \mathrm{~m}$. At the same time, we did not consider the impact of centrifugal acceleration as the main artifact of the clinorotation method on the variance in mycelium growth coefficient, since the value of the centrifugal acceleration was insignificant, amounting to $0.00343 \pm$ $\pm 0.0014 \mathrm{~m} / \mathrm{s}^{2}$. In these conditions, it was determined that the impacts of the g-level, the duration of the exposure and their interaction were statistically significant, namely, the $\mathrm{p}$-values for these impacts were $1.87 \times$ $\times 10^{-11}, 8.2 \times 10^{-4}$ and $2.98 \times 10^{-5}$, respectively. In addition, the obtained statistical F-values $\left(\mathrm{F}_{\mathrm{obt}}\right)$ for the impact of the g-level, the duration of the exposure and their interaction on the variance in mycelium growth coefficient were 215.18, 10.82 and 19.65, while the critical F-values $\left(\mathrm{F}_{\text {crit }}\right)$ were $8.79,6.33$ and 6.33 (with the consideration of Bonferroni correction), i.e. the zero hypotheses, stating that there was no impact of the glevel, the duration of the exposure and their interaction on the variance in mycelium growth coefficient, were rejected. It is noteworthy that a share in the variance in mycelium growth coefficient, conditioned by the glevel, was $73.1 \%$, while the other shares in this variance, conditioned by the duration of the exposure and the interaction of these factors, were 7.3 and $13.3 \%$, respectively. In this study the mycelium growth coefficient was approximately 3.4, 2.5, 1.6 times higher for the clinorotated mycelium compared against the mycelium from the control group $(1 \mathrm{~g})$ on day 5,10 , and 15 of the cultivation respectively. Thus, it was demonstrated using the mycelium of the model organism Agaricus bisporus that uniaxial clinorotation (cultivation in simulated microgravitational conditions) of the gilled mushrooms stimulated their growth and development. It was also found that the impact of the g-level on the variance was the major factor, while the impact of the duration of the exposure was a minor one. 
However, there are still many questions to be answered. For instance, it is not clear which impact slow centrifugation and biaxial clinorotation have on vital activity of gilled mushrooms and on the course of viral infections of plants. In addition, there are no data on the specificities of the impact of clinorotation on the fruiting bodies of this model organism and other species of Agaricales order. The kinematic specificities of clinorotating the samples using the ground-based facility Ekoloh also require detailed studies. The improvement of this technology and its successful application require answering these and other questions.

Uniaxial clinorotation stimulates growth and development of the mycelium of gilled mushrooms (Agaricales). In addition, clinorotation is an efficient way of treating viral infections of plants. These effects of clinorotation have opened new venues for this technology. On the one hand, clinorotation may accelerate the cultivation of stock cultures of gilled mushrooms which, in its turn, will also accelerate and facilitate obtaining high quality and ecologically friendly fungal material. Many kinds of fungal material are currently used in food and pharmaceutical industry. Thus, this technology may be introduced into the abovementioned industries. On the other hand, clinorotation may be used to obtain virus-free propagating material of plants. Moreover, this technology may be applied to treat some small plants, infected by viruses, for instance, ornamental plants. As viral diseases aggravate the productivity and other relevant characteristics of different plants considerably, this technology will be useful for agriculture and forestry as well as different industries, using plant material. Therefore, this technology may have a wide scope of application.

Adherence to ethical principles. No humans or animals have been used as the objects of this study.

Conflict of interests. The authors do not have any conflict of interests.

Financing. This study was not financed by any grants.

\section{Кліностатування як перспективна та екологічно безпечна біотехнологія у сільському господарстві та деяких галузях промисловості}

\author{
А. Л. Бойко ${ }^{* 1}$, Н. П. Сус ${ }^{1}$,
} О. А. Бойко ${ }^{2}$, А. В. Орловський ${ }^{3}$

\footnotetext{
${ }^{1}$ Інститут агроекології і природокористування НААН, 03143, Україна, Київ, вул. Метрологічна, 12

${ }^{2}$ Національний університет біоресурсів і природокористування України, 03041, Україна, Київ, вул. Героїв Оборони, 15
}

${ }^{3}$ Інститут садівництва НААН, 03027, Україна, Київська обл., Києво-Святошинський р-н, с. Новосілки, вул. Садова, 6

E-mail: boiko.anatolii@email.ua*,email@nazariy-sus.com, olga_bojko@ukr.net,mumuk6500@gmail.com

Мета. Вивчити прямий і непрямий вплив кліностатування на життєдіяльність пластинчастих грибів (Agaricales) на прикладі міцелію модельного організму Agaricus bisporus, якого кліностатували наземною установкою «Еколог». Методи. Міцелій Agaricus bisporus культивували на середовищі з агаром та екстрактом компосту. Мікрогравітаційне середовище було симульовано методом одновісного кліностатування за допомогою наземної установки «Еколог». Міцелії Agaricus bisporus експериментальної групи кліностатували 4 год на день впродовж 15 днів. Зразки контрольної групи культивували в нормальних (1 g) умовах. Значення симульованого прискорення вільного падіння становило $3,5 \times 10^{-4} \mathrm{~g}$ за частоти обертання 2,5 об/хв та радіусу обертання 0,05 м. Відцентрове прискорення, яке діяло на кліностатований міцелій Agaricus bisporus, становило $0,00343 \mathrm{~m} / \mathrm{c}^{2}$. Двофакторний дисперсійний аналіз показав, що і ефекти рівня g, і тривалість впливу, i їх взаємодія були статистично значущими. Водночас, 73,1 \% дисперсії коефіцієнта росту міцелію було викликано дією симульованого значення g, тобто тривалість впливу була другорядним фактором. Результати. Кліностатування стимулювало ріст і розвиток міцелію пластинчастих грибів. Зокрема, у цьому дослідженні кліностатований міцелій Agaricus bisporus мав приблизно в 3,$4 ; 2,5 ; 1,6$ рази вищий коефіцієнт росту міцелію, ніж міцелій, вирощений в стаціонарних умовах $(1 \mathrm{~g})$ на 5-й, 10-й і 15-й день культивування відповідно. Водночас, ріст кліностатованих міцеліальних колоній Agaricus bisporus, на відміну від міцеліальних колоній контрольної групи, був асиметричним. У мікрогравітаційному середовищі, яке було симульовано наземною установкою «Еколог», напрям вектора прискорення вільного падіння щодо колоній міцелію постійно змінювався. Водночас різні органи Agaricus bisporus характеризуються гравітропізмом різної спрямованості. Таким чином, безперервні зміни напряму вектора прискорення вільного падіння щодо міцелію, ймовірно, спричинили безперервну переорієнтацію клітин міцелію щодо вектора прискорення вільного падіння i, як наслідок, різноспрямований асиметричний ріст. Крім того, відцентрове прискорення, яке генерується під час кліностатування, є механостимулятором, який може викликати стресові реакції у різних живих систем. Прискорений ріст є однією з стресових реакцій. Водночас, внаслідок дії відцентрового прискорення міцелій міг механічно розширюватися на середовищі. Однак відцентрове прискорення було незначним, і тому ми вважаємо, що основний ефект був викликаний мікрогравітацією. Висновки. Оскільки кліностатування 


\section{CLINOROTATION AS A PROMISING AND ENVIRONMENTALLY FRIENDLY BIOTECHNOLOGY}

стимулює ріст і розвиток пластинчастих грибів і $\epsilon$ ефективним методом формування безвірусного садивного матеріалу різних видів рослин, ця технологія потенційно може мати широку сферу застосування. Ця технологія може використовуватися в сільському господарстві, лісовому господарстві та різних галузях промисловості, в яких використовується сировина з рослин і чи грибів, наприклад в харчовій, фармацевтичній, текстильній промисловості тощо.

Ключові слова: Agaricus bisporus, кліностатування, симульована мікрогравітація, міцелій, Agaricales.

\section{REFERENCES}

Anken R. (2013) Simulation of Microgravity for Studies in Gravitational Biology: Principles, Devices and Appl. Cur. Biotechnol. 2(3):192-200. doi: 10.2174/22115501113029990012.

Arunasri K, Adil M, Venu Charan K, Suvro C, Himabindu Reddy S, Shivaji S. (2013) Effect of Simulated Microgravity on E. coli K12 MG1655 Growth and Gene Expression. PLoS ONE. 8(3):e57860. doi: 10.1371/ journal.pone. 0057860 .

Batitucci G, Brandao CFC, De Carvalho FG, Marchini JS, Pfrimer K, Ferrioli E, Cunhad F Q, Papotic M, Terrazasa SIBM, Junqueira-Francob MVM, Silva ASR da, Freitas $E C$. de (2019) Taurine supplementation increases irisin levels after high intensity physical training in obese women. Cytokine, 123:154741. doi: 10.1016/j. cyto.2019.154741.

Beysens DA, van Loon JJWA. (2015) Generation and Applications of Extra-Terrestrial Environments on Earth. Generat. Appl. Extra-Terrestrial Environ. Earth. 1-318. doi: $10.13052 / \mathrm{rp}-9788793237544$.

Brungs S, Egli M, Wuest SLM, Christianen PC, van Loon WAJJ, Ngo Anh TJ, Hemmersbach R. (2016) Facilities for Simulation of Microgravity in the ESA GroundBased Facility Programme. Micrograv. Sci. Technol., 28(3):191-203. doi: 10.1007/s12217-015-9471-8.

Brungs S, Hauslage J, Hemmersbach R. (2019) Validation of Random Positioning Versus Clinorotation Using a Macrophage Model System. Micrograv. Sci. Technol. doi: 10.1007/s12217-019-9687-0.

Corrochano LM, Galland P. (2016) 11 Photomorphogenesis and Gravitropism in Fungi. Growth, Different. Sexual. 235-66. doi: 10.1007/978-3-319-25844-7_11.

Furdychko O, Bojko A, Dem 'ianiuk O, Tsvigun V. (2020) Virus diseases of plants in agrocenosis and forest ecosystems: diagnostics and prevention. Visnyk Agrarnoi Nauky, 98(2):5-11. doi: 10.31073/agrovisnyk202002-01.

Herranz R, Anken R, Boonstra J, Braun M, Christianen PCM, de Geest M, Hauslage J, Hilbig R, Hill RJA, Lebert M, Medina FJ, Vagt $N$, Ullrich $O$, van Loon JJWA, Hemmersbach R. (2013) Ground-Based Facilities for Simulation of Microgravity: Organism-Specific Recommendations for Their Use, and Recommended Terminology. Astrobiol. 13(1):1-17. doi: 10.1089/ast. 2012.0876.

Hirt C, Claessens S, Fecher T, Kuhn M, Pail R, Rexer M. (2013) New ultrahigh-resolution picture of Earth's gravity field. Geophysical Research Letters. 40(16):4279-83. doi:10.1002/grl.50838

Kim YJ, Jeong AJ, Kim M, Lee C, Ye S-K, Kim S. (2017) Time-averaged simulated microgravity (taSMG) inhibits proliferation of lymphoma cells, L-540 and HDLM-2, using a 3D clinostat. BioMedical Engineering OnLine. 16(1). doi: 10.1186/s12938-017-0337-8.

Mishchenko LT, Boyko AL, Chernyuk SO. (1999) The influence of microgravitation on characteristics of viruses of striped mosaic wheat in Triticum aestivum. Biopolym. Cell. 15(4):319-23. doi: 10.7124/bc.00052d.

Moore D. (1991) Perception and response to gravity in higher fungi - a critical appraisal. New Phytologist. 117(1):3-23. doi: 10.1111/j.1469-8137.1991.tb00940.x.

Nevalainen H. (eds) (2020) Grand Challenges in Fungal Biotechnology. Grand Challenges in Biology and Biotechnology. doi: 10.1007/978-3-030-29541-7.

Qian AR, Li D, Han J, Gao X, Di SM, Zhang W, Hu LF, Peng Shang (2012) Fractal Dimension as a Measure of Altered Actin Cytoskeleton in MC3T3-E1 Cells Under Simulated Microgravity Using 3-D/2-D Clinostats. IEEE Transactions on Biomedical Engineering. 59(5):137480. doi: 10.1109/tbme.2012.2187785.

Siamwala JH, Majumder S, Tamilarasan KP, Muley A, Reddy SH, Kolluru GK, Sinha S, Chatterjee S. (2010) Simulated microgravity promotes nitric oxide-supported angiogenesis via the iNOS-cGMP-PKG pathway in macrovascular endothelial cells. FEBS Letters. 584(15): 3415-23. doi: 10.1016/j.febslet.2010.06.039.

Siamwala JH, Reddy SH, Majumder S, Kolluru GK, Muley A, Sinha S, Chatterjee S. (2010) Simulated microgravity perturbs actin polymerization to promote nitric oxide-associated migration in human immortalized Eahy926 cells. Protoplasma. 242(1-4):3-12. doi: 10. 1007/s00709-010-0114-z.

Sus N, Orlovskyi A, Boyko O, Tsvigun V, Boyko A. (2018) Influence of modeled microgravity on tobacco mo-saic virus. Ecol. Noospherol. 29(2):138-41. doi: 10.15421/031822.

Sysoeva MA, Urazlina LN, Khabibrakhmanova VR, Grigoryeva TV, Sysoeva EV. (2020) Isolation of the Inono-tus obliquus chaga mushroom strain and intensification of a culture growth during solid-phase cultivation. Proceedings of Universities. Appl. Chem. Biotechnol. 10(1):95-106. doi: 10.21285/2227-2925-2020-10-1-95-106.

Van Loon JJWA. (2016) Centrifuges for Microgravity Simulation. The Reduced Gravity Paradigm. Front. Astronom. Space Sci. 3. doi: 10.3389/fspas.2016.00021. 